\title{
THE CIRCULATION OF POWER AND KNOWLEDGE
}

In the humoral theory discussed in the previous chapter, a set of physiological factors determine a diffuse pattern of individual and social behavior at each stage of life. The young man whose body has too much heat is likely to be vulnerable to passions, his impulsive reactions can have dangerous consequences when it comes to governing others. By contrast, the elder (throughout this chapter I will speak of the "riper" man, not the decrepit one on his deathbed) being cooler, is more prudent and rational; his self-control is a major asset when it comes to making wise decisions for the common welfare. ${ }^{1}$

In every society, age serves as a basis for the allocation of different roles that define its members' mutual relations and activities. Sociologist Max Weber observed that in a conservative community that identifies itself with its past, the aged man expects obedience from the young because the social criteria for excellence include knowledge, experience, and spiritual and moral resources. ${ }^{2}$ On the other hand, in a milieu where military values prevail, the emphasis is on youthful, physical vigor. Old age, then, initiates a process of disengagement from an earlier role: the elder's diminished position and status go along with limited social opportunities or withdrawal from the public sphere, and resignation in the face of loss. Renaissance Italian and French societies corresponded more or less to traditional age-grade systems favoring the elderly. Since Antiquity, an adult man kept his rights (legal, financial, political, civil, and professional) up to his death and appointments could be made at advanced ages. The notion of retirement (and of funds given to retirees by the state) became official only in eighteenth-century France; ${ }^{3}$ before that time, the privileges accorded to the elderly generally took the form of exemption from certain dutiessome forms of military service, for instance—rather than positive benefits. ${ }^{4}$

1 See chapter 1.

2 Max Weber, The Theory of Social and Economic Organization, transl. A.-M. Henderson and T. Parsons (New York: Free Press, 1947) p. 346.

3 See Troyansky, Old Age in the Old Regime, p. 56.

4 Exemptions from different forms of military service were usually granted to those who had reached the age of sixty, or sometimes seventy. See Sulamit Shahar, "The Middle Ages and Renaissance", p. 75 . 
In any society there are relations of power that permeate and constitute the social body, Foucault observes. By "power," he meant a cluster of relations, a heterogeneous ensemble of strategies and techniques continually at work in human exchanges rather than an exterior force imposed upon an individual. His work focused on the practices and the effects of this micro-physics of power: on the way things "work at the level of ongoing subjugation, at the level of those continuous and uninterrupted processes which subject our bodies, govern our gestures, dictate our behaviors, etc." Although the exercise of power remains linked to individuals, it is not tied to specific persons, Foucault contends; in fact, it is the other way around: individuals depend on power relations in order to define themselves. The instability and reversibility of these relations allow creative responses and resistances to power. ${ }^{6}$ Indeed, power is not necessarily repressive, but is also productive of knowledge. Foucault's discussion of the confession ritual and of the prohibition of some sexual behaviors provides suggestive examples of mechanisms of power and surveillance that put into circulation apparatuses of knowledge conceived in terms of social relationships. Rather than seek to eradicate the repressed phenomenon, these mechanisms reveal it, keep it alive, and acknowledge its constitutive role.

This chapter elaborates on Foucault's investigation of the relations between power and knowledge in a different field: it examines the young-versus-old confrontation in the body of the Renaissance ruling and intellectual elite of both sides of the Alps. My goal is to show how these relations open themselves up to various forms of self-fashioning and self-knowledge. Moreover, their political impact deserves scrutiny: at stake was nothing less than social harmony and peace. In this respect, the proliferation of Renaissance representations of old men as advisors, councilors, and pedagogues takes its full meaning in the perspective of the previous chapter. The care for the self appears like a pedagogical, moral, and also ontological condition for the constitution of a good leader. Since one must first establish a proper relationship to oneself in order to be capable of exercising power over others, the elder is in an ideal "position" to shape the body politic and direct the behavior of others by passing on

5 M. Foucault, “Two Lectures”, in Michel Foucault: Power/ Knowledge: Selected Interviews and Other Writings, 1972-1977, ed. C. Gordon (Brighton: Harvester Press, 1980), p. 97. See also Foucault, The History of Sexuality, vol. 1, p. 93 defining power as "a complex strategic situation in a particular society."

6 Foucault, The History of Sexuality, vol. 1, p. 93. 
to the young generation the knowledge of some rules and the practices that these rules regulate.

Portraits of old men as educators drew upon a wide variety of classical, medieval, and biblical sources; yet it is safe to say that every defense of old age referred to Cato Maior De Senectute, in one way or another. Cicero's dialogue confers upon the octogenarian Cato the Elder the role of pilot of the ship of the state and praises a lifelong practice of virtues that confers dignity at the end of a long and honorable career. The number of editions, comments, and translations of Cicero's dialogue during the Renaissance attests to its immense popularity as well as to its author's reputation. Learned people could easily identify in De Senectute's emphasis on Cato's pivotal function in the social and political spheres the imprint of a philosophical and medical tradition that included Plato and Hippocrates. In addition, they could find many similarities between Cato the Elder's belief in the soul's immortality and their own Christian background. A remark made by one of the protagonists of Erasmus's colloquium Convivium religiosum (The Godly Feast) could epitomize this perspective. Commenting on Cato the Elder's words in De Senectute, Chrysoglottus says:

While most of Marcus Tullius [Cicero] books on philosophy seem to breathe something of divinity, I consider the one on old age, written when he himself was old, his swan song, as the Greek proverb puts it. Today I reread it and learned the following words by heart, since they pleased me most of all: "... I depart from this life as from an inn, not from a home. Nature gave us a lodging to stop at, not to settle down in. O glorious day when I shall join that company of souls and leave this tumult and contagion!" Thus far Cato. What could a Christian have said more reverently? I wish the conversations of monks, or those of monks and nuns, were all like this talk of an old pagan with young pagans. ${ }^{7}$

More broadly speaking, De Senectute gave generations of readers a stock of philosophical, political, and rhetorical arguments to support the view that the management of affairs of state and the education of the young should be the elders' specific tasks. In Cicero's text the octogenarian Cato the Elder is no longer able to participate in physical military activities, but his later years mark his transition to a more valued public role: old age is a period of enhancement and opportunities, rather than diminution and loss. Cato embodies his fellow citizens' political expectations; in fact, he lives for the common good rather than for himself. He is a role model in

7 Erasmus, Convivium religiosum in The Complete Works, vol. 39, Colloquies, ed. and trans. C. R. Thompson (Toronto: Toronto University Press, 1997), pp. 192-93. 
his community and his prestige extends beyond the political arena to the private domain of everyday life. Not only does he perform important functions in advisory councils, he also teaches the young generation, and his own emploi du temps is exemplary. In short, his speaking ability and wise counsels, his activities and even his leisure shape every aspect of Rome's public life.

The most astute Renaissance writers did not simply reproduce $D e$ Senectute's arguments (to which I shall return later) but combined them with other sources, transposed them to their own historical context and to other circumstances, challenged them or ironically subverted them. Here I would like to examine new forms of elders' identities that emerged from Petrarch's Letters of Old Age, Castiglione's Book of the Courtier, and Montaigne's Essais. In a period of political turmoil and especially in the context of the civil wars of Montaigne's late sixteenth-century France, the circulation of power and knowledge between generations became an increasing matter of concern. Montaigne's views on age and intergenerational relations take their full meaning when considered in this broader intellectual context.

\section{Petrarch}

Petrarch shared Cato the Elder's belief in De Senectute that those advanced in years have a crucial role in the perpetuation of a society's moral, cultural, and sacred heritage. He was, however, strongly critical of Cicero for having wished in his later years to return to a life of politics, with its many useless quarrels; such a choice is inappropriate for a scholar and a sage, he contended (Fam. XXIV, 3). Yet his epistolary work reflects his attempt to exert political influence at the highest levels, while at the same time preserving his intellectual independence and inhabiting a world of literary, moral, and spiritual reflection. His emphasis on his age in the Letters of Old Age fully participated in this dual goal.

My argument will focus on three broad perspectives. First, Petrarch's relations with Pope Urban V regarding the return of the Holy See to Rome, on the one hand, and his discussion of the best government in a letter to Francesco da Carrara on the other hand, will serve as case studies of the literary and psychological effects of the author's self-portrait as an aged man. Second, any investigation of Petrarch's self-portraits in his epistolary work is bound to be incomplete if attention is not paid to the dispositio of his letters. At first glance, the organization of the Letters of Old Age 
seems to reflect the randomness of a writer somehow caught up in his addressees' lives and in current concerns. A closer look, however, reveals a careful orchestration in the letter series that placed Petrarch at the center of a network of relations of power and knowledge between one generation and another. Third, by focusing on his experience of aging, Petrarch insured a bond with dead, living, and unborn correspondents, and paved the way for his own immortality. At all three levels, the fashioning of an aging identity was a crucial aspect of a process of self-understanding. The comparison between the Letters of Old Age and De Remediis utriusque fortunae (written about the same time) provides a suggestive way of examining further implications of this question.

As he became more famous in his later years, Petrarch acquired a correspondingly elevated sense of his own public status in the ever-changing cycle of events, even if he was unable to control them. In the second letter of book I's Letters of Old Age, he told his friend Francesco Nelli that the Roman Emperor Charles IV and the French King John II both summoned him to work for them; the emperor even gave him a golden bowl as an advance. If these invitations were not enough, Pope Innocent VI (Urban V's predecessor) asked him to become his secretary, and sent him some gifts. Petrarch's letter is dated sometime between 1361 and 1362 , when he was age fifty-seven or fifty-eight. He joked about his age and wrote to Nelli that old men are often accused of avarice, but such was not his case. The elders, he added, are also said to be more obedient than young ones, yet he had no intention of accepting any of these positions (Sen. I, 2, pp. 3-5/ Lettres, vol. 1, pp. 23-27). The three offers stressed his international reputation, but more was at stake in the letter than the desire to boast of his prestige among the religious and political elite. The following letter to the same correspondent (dated from Padua, June 8, 1362), placed these invitations in the context of the day. War was raging everywhere, and the roads around Padua were blocked in whichever direction Petrarch tried to go. There was turmoil in Venice and in Western Lombardy; there was fighting in Tyrol and it was impossible to travel to the emperor's court in Bohemia because the German border along the Alps was not safe (Sen. I, 3, p. 10/ Lettres, vol. 1, pp. 37-41).

In his response to the offer from the papal court, the writer adopted the posture of a wise and experienced aged counselor. His lifelong experience was coupled with stereotypical qualities such as a sound judgment and frankness. In fact, he contended that telling the truth was not only an aged man's right but also his duty. He officially declined the pontifical secretary position in book I's fourth letter (addressed to Cardinal Elie de 
Talleyrand, Bishop of Albano). The humanist stressed his age, and therefore his lack of interest in honor and wealth. More importantly, he pointed out the atmosphere of calumny, hypocrisy, and hatred at the papal court. A position in such a milieu would seriously have limited Petrarch's freedom of speech, preventing him from acting according to his own moral precepts. Book I's fifth letter to Boccaccio summed up his general feeling: he was disgusted with Italian politics and firmly determined to stay away from that atmosphere of envy and corruption (Sen. I, 5, p.15/ Lettres, vol. 1, pp. 47-48). His desire to spend his later years in a studious retreat revealed the intellectual independence of a man who had only contempt for earthly vanity. Petrarch's personal life reinforced his wish to withdraw from the public sphere: death looms over the Letters of Old Age from the onset. In book I's opening letter to Nelli, Petrarch mourned the death of many close friends, and of his own son Giovanni (Sen. I, 1). Indeed, old age is traditionally a time of loneliness; in addition to the loss of loved ones, one's own end seems more and more imminent.

However, Petrarch's preparation for the afterlife and his concern for literary immortality did not exclude his involvement in public affairs. The election, on September 28, 1362, of Pope Urban V (Guillaume de Grimoard) as successor to Innocent VI increased Petrarch's hope to renew the Church, and to bring unity and peace to Italy. He trusted the new pontiff's moral rectitude and reputation for integrity. For Petrarch, the government of self was the predicate for any constructive engagement with social institutions. Urban V was in his fifties, the "prime" of old age"green old age" as Galenic medicine put it — that is, at an age when wisdom and prudence are predominant in a man's general behavior. ${ }^{8}$ The Letters of Old Age's book VII contains only one letter, dated June 29, 1366 (four years after the Pope's election) urging Urban V to leave Avignon, which had been the papal residence since August 1308, and return the Holy See to Rome at once. Throughout this long letter, Petrarch established himself as a perceptive commentator on human nature, rather than as a political analyst; a wise and experienced aged moralist pinning his hopes on virtuous individuals as the best means of promoting security and faith. Following up on his appreciation for Urban V's affable manners, the writer praises the pope's battle against self-promotion and corruption in the Church (Sen. VII, 1, p. 229/ Lettres, vol. 2, p. 303). The pope's name (Urbanus: urban, gentle), Petrarch noted, was the very sign of his virtues,

8 See chapter 1, the section on Petrarch. 
and therefore of his ability to champion faith. Moreover, who could deny that his name signaled his attachment to the city (urbs) of Rome? (Sen. VII, 1, p. 236). ${ }^{9}$

The letter gave a bleak image of the political and moral climate of the day. Rome was in ruins, its temples crumbling; vice ruled the Eternal City; the Church members delighted in sensual pleasures, and were more interested in wine than in religion. To this general disarray, Petrarch added an international threat: the Turks were fighting Christendom. God himself urged the Holy See to return to Rome. After such an ardent plea, any reader would have been inclined to bestow the pope's official title of "Vicar of Christ" on the sixty-two-year-old Petrarch rather than on Urban V. The writer portrayed himself as the ambassador of the Christian community as a whole, for in his view his letter met Christ's expectation and approval. He closely monitored the way his behavior would be perceived by his readers; his plea to Urban V conveyed his loyalty to his country and his Christian devotion. The contrast was striking between his unselfish concern for the common good and for God on the one hand, and on the other hand, the corruption of the ambitious flatterers who filled the papal court. From the outset, he told the pope that he had a longtime habit of being outspoken with both important and less important people, but especially with the more powerful ones who, he hoped, would reward his frankness and forgive his mistakes (Sen. VII, 1, p. 228). ${ }^{10}$ Politics is a struggle for power, yet it must be tempered by a will to listen to a truth that may be difficult to embrace. Petrarch's freedom of expression and independence of mind were inseparable from the exercise of an auctoritas traditionally granted to the elder. Indeed, he pointed out "Solon's famous answer to Pisistratus" (quoted in Cicero's De Senectute (20, 72, p. 84)), along with a similar story told by Valerius Maximus (VI, 2, 10):

When asked by Pisistratus, the tyrant of Athens, how he had the nerve to stand up to him so steadfastly, he answered, "Because of my old age." Then there is that saying of Marcus Castricius, with different words but the same idea; when the angry Carbo, consul in name but tyrant in reality, said

9 "Quomodo enim, queso, et Urbanus diceris et, nominis huius originem, Urbem fugis?" (Lettres vol. 2, p. 321).

10 "consuetudo mea scribendi non tantum pari fidutia parvis ac magnis, sed eo semper alacrius quo maioribus sim scripturus, a quibus et bene dictorum ampliorem gratiam et errorum promptiorem veniam sperem." (Lettres, vol. 2, p. 299). 
threateningly that he had many swords, he replied, "And I have many years." (Sen. VII, 1, p. 228). ${ }^{11}$

The self-control of Pisistratus and Marcus Castricius commanded respect. Petrarch shared these old men's determination and their proud refusal of any form of threat or enslavement. He even perfected their exemplary attitude, since his position embodied classical (pagan) ethical ideals as well as religious virtues: he represented himself as a Christian Ancient. Old age justified his "frankness or truthfulness, nerve or conviction;" moreover, it served as justification for the length of his exhortation to the pope (Sen.VII, 1 , p. 244/ Lettres, vol. 2, p. 373) since loquacity is a stereotypical attribute of old age. In speaking the truth, Petrarch does not simply invite the pope to act, but also reveals to the reader who he is: a man whose ethical priorities and religious principles shape his relationship to himself and to others. Ultimately, the objective of his frankness is not so much the salvation of Rome as a matter of self-fashioning: speaking the truth finds its fulfillment in the "formation of a certain way of being, a certain way of doing, a certain way of conducting oneself around other people or another person," in Foucault's words. ${ }^{12}$

Now a letter is a delayed exchange between two parties who occupy separate and often distant positions in space and in time. Since the writer communicates his views without interruption, challenge, or reaction from his correspondent, he should be circumspect about the wording of his text. Petrarch took some precautions to ensure the positive reception of his plea: he asked Francesco Bruni (one of his Florentine admirers, who became papal secretary after Petrarch declined the position) to solicit the advice of two of Petrarch's close friends (Philippe de Cabassoles and Agapito Colonna) before sending the letter to Urban V. ${ }^{13}$ The letter was well received. After numerous consultations with members of the French and Italian clergy, Urban V left Avignon a few months later, on April 30, 1367.

The Letters of Old Age's book IX contains only two letters commenting on this event: first, an enthusiastic letter to the pope hailing his return to Rome and praising the triumph of faith and virtue over vice (Sen. IX, 1);

11 "Unde est responsum illud famosissimum Solonis: quem cum Pisistratus Atheniensium tyrannus interrogaret qua fidutia sibi tam constanter obsisteret, "Senectute", inquit. Et illud Marci Castricii, verbo aliud, idem sensu; cui cum iratus Carbo, consul nomine, re tyrannus, inter minas diceret "multos se gladios habere", respondit: "Et ego annos." (Lettres vol. 2, p. 301).

12 M. Foucault, Cours au Collège de France 1984. Le gouvernement de soi et des autres II (Paris: Gallimard, 1984), 8 février. My translation.

13 Petrarch, Lettres, vol. 2, p. 296. 
second, a more personal letter to Francesco Bruni stressing Petrarch's role in this victory (Sen. IX, 2). From books VII and IX of the Letters of Old Age's account, it was clear that Petrarch masterminded the whole operation from beginning to end; the pope had only carried out the humanist's plan. Petrarch's joy, however, was brief. Fleeing the political turmoil of Rome, Urban V returned to Avignon in 1370, and soon passed away. Two letters in book XIII elaborated on these developments. Letter 12 to Philippe de Cabassoles (dated between 1372 and 1373) echoed a previous letter to him written during Innocent VI's papacy (Sen. I, 4): Petrarch declined yet another invitation to work at the papal court and expressed his bitterness. He had no respect for the circle of hateful and envious advisors surrounding the new pontiff Gregory XI. In his next letter to his friend Bruni, he was convinced that the cardinals the pope had just appointed would speak against his own faithful devotion to the Church (Sen. XIII, 13, p. 507). ${ }^{14}$ In fact, he did not trust Gregory XI, he wrote to Bruni. Thinking about his hope at the time of Urban V's election (Sen. XIII, 14, p. 513/ Lettres, vol. 4, pp. 197-99), he wished the deceased pope could have read his letter of reproach for having abandoned Rome. He was convinced that Urban V would have taken action, as he had after receiving Petrarch's plea to leave Avignon (the French Babylon) in 1366 (Sen. VII, 1). The virtuous Urban V was the only one who could have saved the Church, but he had been caught between conflicting interests and had been the victim of deceitful advisors as well as venomous enemies. Was the pontiff's subsequent death due to poison? Petrarch did not rule out a plot by some members of the papal court, given the Church's spiritual disintegration (Sen. XIII, 14, p. 515/ Lettres, vol. 4, p. 211).

About two years after these tragic events, he had abandoned all hope for moral and political action. Once again, his age became the pretext for promoting his studious retreat and his preparation of the afterlife. Yet might there be a second evaluation of Petrarch's old age, at odds with this flattering self-portrait blending pagan and Christian ideals? To what extent did his letters reflect his frustration and his feeling of living in exile? His lifelong experience and erudition had proved useless when it came to dealing with the Church's spiritual crisis. His failed embassy and subsequent retreat acknowledged a gap: he belonged to a past generation,

\footnotetext{
14 "credere te papam optime voluntatis erga me, veruntamen, propter turbam famelicorum cardinalium quos de profundis ad eum statum nuper assumpserat, nec voluntatem in actum traducendam nec magnificum inde michi nunc aliquid te sperare." (Lettres, vol. 4, p. 193)
} 
whose ethical and Christian values lacked respect among powerful contemporaries. He wrote to Francesco Nelli $($ Sen. I, 3) that his enemies might have found him too old and physically weak to hold the influential position of apostolic secretary, yet he was strong enough for peaceful labors.

Never did Cato the Elder have to confront such problem in Cicero's De Senectute: at age eighty-four he was the indisputable center of Rome's public life. As such, he conveyed Cicero's personal ambitions of power at the very moment when the sexagenarian author was losing his political influence. De Senectute's eloquent defense of gerontocracy expressed Cicero's own frustrations; Petrarch's reactions were very different, at least as portrayed in his letters concerning the return of the Holy See to Rome. In the context of a political crisis that he saw mostly in moral terms, the posture of Petrarch the old man conveyed both his lucid view of the situation and his limited power of action. In contrast to Cato the Elder's proud authority over his fellow citizens, growing old taught Petrarch patience as he witnessed with increasing irritation and sadness the spiritual and political turmoil of the day.

In fact, he gave his readers the point of view of an aged letter-writer who had assigned himself the only field of public life worthy of him: the wider regions of immortal and universal fame. As Seneca observed in his Letters to Lucilius (a major reference of Petrarch's correspondence), the wise old man is never apart from public life even if he withdraws. Perhaps "he has abandoned one little corner thereof," but he is in fact above it:

he understands how lowly was the place in which he sat when he mounted the curule chair or the judgment-seat. Lay this to heart-that the wise man is never more active in affairs than when things divine as well as things human have come within his ken. (LXVIII, 2, p. 45)

Other epistles in Letters of Old Age elaborated on a similar view and conveyed the way Petrarch saw the role of literature in the political sphere. Book XIV, for instance, contains two letters to Francesco da Carrara, Lord of Padua, that define Petrarch's conception of the best government. In book VII, the humanist gave Urban V no practical advice for fighting vice and corruption in the Church; likewise, book XIV offers few insights on the state's administrative structure, inasmuch as political questions are associated to certain forms of self-relation. For Petrarch, the best form of government depends on the prince's personal qualities, and Francesco da Carrara embodied all of them. The enumeration of his virtues (moral rectitude, constancy, fairness, faith, magnanimity, humility, mercy, paternal love for one's fellow citizens, concern for the common good, and so on) 
mostly followed medieval advice books for city magistrates, and Roman sources, including Seneca. ${ }^{15}$ Once again, Petrarch avoided accusations of being a flatterer by affirming his commitment to truth. The end of his second letter to Francesco da Carrara struck a tragic tone in this respect, for it alluded to a failed attempt to poison Francesco (Sen. XIV, 2, p. 555/ Lettres, vol. 4, p. 313). The presumed author of the plot was Francesco's own brother whose name Petrarch purposely omitted since he did not deserve to be remembered.

We cannot deny that there was a strong element of status-granting in Petrarch's representations of Francesco da Carrara and Urban V as virtuous and dedicated leaders. In both cases, Petrarch's self-portrait in old age offered resistance to a context deprived of moral and religious values. Instead of sliding into old age, the writer showed himself ascending to it after the slippery journey of youth and its clouds of passions. His choice of life and the way he managed the only things that depended on him-his body, his mind, and most importantly, his time-commanded respect. ${ }^{16}$ Like Cato the Elder in Cicero's De Senectute, Petrarch's age served to justify his freedom of expression and his constancy, to establish his moral credentials as a purveyor of true representation, and to deflect the accusation of flattery that was always suspected behind the panegyrics of powerful men. Moreover, as a man dedicated to scholarship, he had read and meditated upon countless historical accounts; he therefore understood contemporary politics within a broader intellectual context.

Far from being unmoved by the pettiness and vices of a world he was about to leave, Petrarch forged links with Cicero. The sexagenarian Roman had written De Senectute to persuade the Senate to continue to retain his services. Petrarch, on the other hand, declined the opportunity to stay in office in his later years; yet, like Cicero, he used his eloquence, his age, and his reputation to advocate peace. His correspondence with Urban V and Francesco da Carrara testify to his relentless efforts to motivate members of the religious and political elite, and to foster cooperation when it seemed most difficult. In these letters - and throughout his Letters of Old Age as a whole - he gave advice and urged his contemporaries to withstand the blows of fortune by cleaving to virtue and overcoming libidinous

15 On medieval advice books, see Paul-Oskar Kristeller, Studies in Renaissance Thought and Letters (Rome: Edizione di storia e letteratura, 1956), pp. 262, 56o-64. On Petrarch and Seneca, see P. Stacey, Roman Monarchy and the Renaissance Prince (Cambridge: Cambridge University Press, 2007), pp. 119-20, 140-56.

16 See chapter 1 , the section on Petrarch. 
attachments to secular things. With paternal authority, he attempted to prepare them for public service, embodying the elder's moral responsibility to instruct youth. His letters to members of the young generation such as Giovanni Boccaccio, Francesco Bruni, and Philippe de Cabassoles show him as a teacher and father figure imparting a variety of notions and skills, ranging from the acquisition of a literary style to the cultivation of moral and religious values. To his correspondents (and to the wider audience of his epistolary works) he passed along a Christian and classical heritage in which he included himself.

Book VIII of the Letters of Old Age provides us with yet another aspect of Petrarch's fashioning of his self-portrait in later life. This aspect is unrelated to De Senectute's model for it deals with the series on the construction of letters. Book VIII contains eight letters that appear in chronological order (with the exception of letters two and three); all are written in Pavia (though the seventh letter does not indicate location) over a period of exactly one year. The first, to Boccaccio, is dated July 20, 1366 at dawn, on Petrarch's sixty-third birthday. The eighth letter, to the same recipient, is written one year later, on July 20, 1367 at dawn, on Petrarch's sixty-fourth birthday.

The first letter begins with general considerations on young and old people's respective tendency to lie about their age, or to hide it, as Petrarch himself used to do. The author reminds Boccaccio that the ancient authorities held various views regarding the onset of old age. He then focuses on an ancient Roman superstition. According to Julius Firminus Maternus and other sources, the seventh and ninth years of life are said to bring destruction, hence the sixty-third one is doubly evil, being the product of two unlucky numbers (Sen. VIII, 1 p. 263/ Lettres, vol. 3, p. 29). Among the dangers that await a person entering the climacteric year are "enormous disaster or death, or physical or mental illness" ("insigni calamitate aliqua vel morte vel morbo corporis aut animi") (Sen. VIII, 1, p. 266/ Lettres, vol. 3, p. 29). Having just entered the dreaded sixty-third year, Petrarch allegedly "disdain[s] the entire matter, and the explanation of it just as much" (Sen. VIII, 1, p. 266/ Lettres, vol. 3, p. 29), and claims that he has never felt so well as on this birthday; moreover, he has no fear of death. Despite his criticism of astrology, however, he was not completely free from anxiety. Book VIII's final letter to Boccaccio expresses his relief at having survived the critical year. He then unmasks the fallacy of superstitions and looks back with amusement and tolerance at his fears. In conclusion, he thanks God who granted him protection, although he does not expect to live forever. He also celebrates the triumph of faith over paganism and 
superstition in the world at large by praising the Christian king of Cyprus's victory in Alexandria, and the return of Pope Urban V to Rome (Sen. VIII, 8, p. 303/ Lettres, vol. 3, p. 103). Ironically, numerological superstitions were at work at the very moment he dismissed them since the news of his sixty-fourth birthday appears in the eighth letter of book VIII: eight times eight make sixty-four.

Cicero was sixty-two years old when he wrote his famous apology of old age in De Senectute; he was killed two years later. Petrarch, however, had read that Cicero had lived sixty-three years. ${ }^{17}$ Book VIII's second (and probably fictitious) letter, to "Unspecified Friends," was Petrarch's own version of Cicero's apology of the twilight years; moreover, he wrote it when he was about the same age as the Roman senator. In De Senectute, Cato the Elder gave four broad reasons that make people fear old age: first, it takes away active work; second, it weakens the body; third, it deprives man of pleasure; fourth, it is not far from death. He countered each in turn. Petrarch's Letters of Old Age, book VIII's second epistle revisited these questions, taking into account other sources of inspiration, including Seneca's Letters to Lucilius. The humanist reiterated Seneca's statement that "life is most delightful when it is on the downward slope, but has not yet reached the abrupt decline" (Ad Lucilium XII, 5, p. 67). Having reached the first phase of old age (Galen's "green age"), he felt in a riper, peaceful and milder season than the previous stages of his life. To a friend who tried to comfort him because of his age, he replied, "if you care for me, do not weep because I am not young; weep because I once was" (Sen. VIII, 2, p. 273). ${ }^{18}$ Looking back on his life as a whole, he could see that he had wasted his youth in the turmoil of his passion for Laura. After this period of "civil war" and inner struggles, he had finally found harmony and peace in his later years. Although he felt physically weaker than in his youth (a physiological fact that Cato the Elder flatly denied in De Senectute), his memory was still excellent. Following Cato's example, he maintained a high level of energy by fasting, and reducing his hours of sleep, and contended that everyone should get into such habits of healthy living and moderation in diet from his earlier years onward. Like Cato, he was convinced that only fools ascribe vices and follies to the winter of life. As Cicero's dialogue made clear, senile debility and melancholy result

17 See Lettres, vol. 4, p. 539 fn. 79 about Petrarch's source (Seneca, Suas. 6, 22).

18 "Noli", "inquam," amice, si me amas, flere quod iuvenis non sum; "fle potius quod iuvenis fui!" (Lettres, vol. 3, p. 43). 
not from the condition of age itself, but from personal weaknesses and bad habits. Cato saw old age as a liberation from the sexual appetite that troubled him earlier in life; thanks to this harmony he enjoyed a serenity unavailable to those still prey to their instincts. Petrarch, on the other hand, still felt the attraction of sensual love, but was no longer subject to its constraints, and was therefore able to focus his attention on intellectual activities. His vast correspondence, and his revisions and completion of previous works were the products of the energy of his later years. His pleasures were perhaps fewer than in his youth, but more meaningful. "Let us cherish and love old age; for it is full of pleasure if one knows how to use it," Seneca likewise observed in his Letters to Lucilius. "Fruits are most welcome when almost over; youth is most charming at its close; the last drink delights the toper... Each pleasure reserves to the end the greatest delights which it contains." (VII, 5, p. 67). Finally, approaching death did not worry Petrarch since the soul is immortal, as Cato the Elder contended in Cicero's De Senectute. In this respect, Petrarch firmly rejected Seneca's temptation to suicide (Ad Luc. LXXVII).

Throughout book VIII's eight letters, there is a continuing resonance of the Ciceronian and Senecan representation of old age as a period of dignity, serenity, wisdom, and inner freedom for a self-motivated man. In this respect, the eight letters echo a series of philosophical commonplaces on later life: they speak of the fallacy of superstition (Sen. VIII, 1), the benefits of old age (Sen. VIII, 2), the widespread and wrong belief in fortune's adversity and in opinions (Sen. VIII, 3), and the importance of friendship (Sen. VIII, 4). They offer thoughts on how to bear grief (Sen. VIII, 5), on preparation for the afterlife through penance and reading (Sen. VIII, 6), and they praise the benefits of a peaceful and solitary retreat in the countryside as opposed to the tensions of an urban lifestyle (Sen. VIII, 7). In contrast to Cato the Elder's exemplary character and role model, Petrarch's self-portrait embodies the will and effort to acquire the values prescribed for the younger generation. Petrarch's smile when describing his superstitious fear of the ominous sixty-third year of his life (Sen. VIII, 1 and 8) epitomizes this attitude. As he grew old, Petrarch had a better understanding of himself; he knew how to judge his past, and rejoiced at having overcome his youthful inner struggles. ${ }^{19}$ As Saint Augustine (another influential model for Petrarch) observed in his sermon Ad Competentes, the wisdom of old age is not a matter of

19 See also chapter 3 , the section on Petrarch. 
being more experienced, but of gradually discerning the meaning of those experiences. As we grow old, we do not "lose" the previous ages we lived, but we see them differently:

By means of these divisions or stages of age, you will not change from one stage to another, but staying the same, you will always know newness. For the second age will not follow so that an end may be put to the first; nor will the rise of the third mean the ruin of the second; nor will the fourth be born so that the third may die; nor will the fifth envy the staying power of the fourth; nor will the sixth suppress the fifth. Although these ages do not all come into being at one and the same, they continue together in harmony with one another in the soul whose relationship with God is right, and they will conduct you to the everlasting peace and tranquility of the seventh stage. ${ }^{20}$

In Augustine's perspective, the advancing from one age to another is a sort of death; hence this process liberates man from the fear of his "real" death, which only involves a migration to a new and better life. In his Letters of Old Age, Petrarch achieved Augustine's measure of transcendence while being at the same time attentive to the political instability and moral corruption of the day.

The final book of the Letters of Old Age contains only one letter, dedicated to "Posterity," which looks forward in time to unborn readers (Sen. XVIII, 1). In contrast, the last epistles of the Letters on Familiar Matters look backward since all their addressees are the Ancients whom Petrarch emulated (Cicero, Seneca, Varro, Quintilian, Livy, Pollio, Horace, Virgil, Fam. XXIV, 3-11). Together, the endings of the two collections secured Petrarch's position in a Republic of Letters unaffected by time. Scholarly interest in the letter to "Posterity" has focused on the details of Petrarch's life of exiles and travels, as well as on his friends and correspondents; I will leave it to others to discuss these aspects of his life. My aim is to suggest a dimension unexplored by scholars: the impact of the aging process on the autobiographical narrative that concludes the Seniles. The final letter to "Posterity" was written between 1370 and 1374, in the last four years of Petrarch's life. From the outset, the author stressed his physical decline. His dim vision forced him to wear glasses; old age has "invaded [his] body which had been very healthy in every age, and surrounded it with the usual array of ills" (XVIII, 1, p. 672). His emphasis on his aged and

20 The passage appears in Saint Augustine, Sermo 216 Ad Competentes, in Patrologia Latina (Paris: Migne, 1863sq.), vol. 178, col. 731. English trans. M. Dove, The Perfect Age of Man's Life (Cambridge: Cambridge University Press, 1986), pp. 48-49. 
weak body stands in sharp contrast with his lust for literary immortality. As evidenced by its full title- "An account of [Petrarch's] background, conduct, and the development of his character and studies" - the letter offers a coherent narrative of its author's life. It retroactively confers meaning on a sequence of events which, no doubt, had different and more complex reasons when they occurred. Petrarch summed up the path of his literary career, settled old scores, repaid some debts, recalled his disappointment when Pope Urban V returned to Avignon, and paid tribute to his patrons, including the Carrara family.

David Guttmann, who has studied cross-cultural patterns of aging, notes that the process of a "life review" occurs often at old age, and is "prompted by the realization of approaching dissolution and death, and the inability to maintain one's sense of personal invulnerability." The autobiographical narrative moves the elder toward "personality reorganization" and provides him with a greater sense of meaning in his life. ${ }^{21}$ In the same way, the letter to "Posterity" represents Petrarch's life as a total history. Its goal is very different from a faithful biographical account; indeed, from its dedication on, the letter situates the writer's persona at the threshold between life and death. With his end approaching, Petrarch portrays himself looking back on his past and forward to what will come next: death and the afterlife, along with ways to secure his literary immortality. His Janus-like perspective in this final letter is an adaptive move to escape oblivion since it allows the aged Petrarch to represent himself as an old and famous writer full of wisdom, experience, serenity, and faith, who has achieved an enviable proximity to God. The purpose of this stylization of existence was not self-love but an attempt to embody a moral and religious message. In a truly Augustinian style, Petrarch describes his old age in terms of conversion; growing old has made him turn away from his youthful, futile and earthly pleasures:

Adolescence misled me, youth swept me away, but old age set me right, and taught me by experience that truth I had read long before: that adolescence and pleasure are vain; or rather, it was the Creator of all ages and times who set me right. (XVIII, 1, p. 672)

Thus for Petrarch old age was a title, a privilege conferred upon his intellectual attainment and spiritual strength. The errors of youth are "best discovered by old age, which bares them for those who concealed them

${ }^{21}$ David Guttmann, "The Life Review: An Interpretation of Reminiscence in the Aged," Psychiatry 26 (1963), p. 67. 
or closed their eyes to them," Petrarch repeated in De Remediis utriusque fortunae's first allegorical dialogue, "Prime of Life" (I, 1, p. 15). ${ }^{22}$ His selfportraits in the Letters of Old Age have many similarities with De Remediis's debates on youth and old age; indeed, both works were written at about the same time. A Renaissance best-seller, De Remediis is a sum of medieval and classical wisdom aimed at helping human beings to negotiate the conflicts between reason and passion as they cope with the vicissitudes of Fortune in an unstable world. Book I presents remedies to the dangers of Fair Fortune (Prosperity); book II offers advice on how to face the blows of Foul Fortune (Adversity). In both books, allegorical characters discuss human dilemmas on a wide range of questions concerning life and death. Two pairs of "Passions"-Hope and Joy, Fear and Sorroware evoked by Fortune's emissaries, Prosperity and Adversity, and assault the human mind. Using eloquence, Reason takes on all of them at once, and with God's help, wins over her enemies. Reason and the four Passions are on stage throughout the two books, but Fortune and humankind are the real protagonists in the debates since the reader is required to exercise judgment, as a rational and virtuous being. In each dialogue, interpretation teaches self-knowledge, humility, patience, and trust in God. ${ }^{23}$

De Remediis's dialogues dealing with the ages of life elaborate on stereotyped attitudes, since Reason shows the reader how to come to terms with growing old, and how to behave accordingly. The genre of the debate reflects Petrarch's fondness for a rhetorical conception of human nature. In book I's first debate on "The Prime of Life," Reason addresses ways of coping with the body's decay. She warns Joy and Hope of the pitfalls of youth, "the most dangerous part of life" (I, 1, p. 13). The overconfident young man forgets that time is fleeting, and that old age is already upon him. How foolish it is not to prepare oneself for the winter of life. Reason suggests a standard Stoic exercise in this respect: from their youth on, Joy and Hope should already imagine themselves as wrinkled and old; most importantly, they should place their trust in eternal matters. The next debate between Joy and Reason on "The Body" elaborates on a similar commonplace: the contrast between the ephemerality of physical beauty and lasting spiritual qualities (I, 2, p. 16). Given the brevity of life,

22 Petrarch, De Remediis utriusque fortunae, trans. Conrad H. Rawski (Bloomington: Indiana University Press, 1991), 2 vols. All further quotations are from this edition and are incorporated into the text. The first number indicates the volume number, the second one the dialogue number.

23 Ibid., p. xxiv. 
one should capitalize on values that remain a source of joy and growth throughout life: faith in God, intellectual endeavors, honest pleasures, and virtue.

Both dialogues convey the importance of age in allocating roles since youth and old age are understood in terms of each other. Aged persons are figures of authority to be revered by youth. In other dialogues, however, the figure of the old person is far from exemplary. In book II's debate "On Old Age," Sorrow severely undermines Cicero's image of wise and serene old age by embodying negative commonplaces of the twilight years: she has a gloomy mood and a grumbling disposition. Sorrow keeps complaining about her wretched body. As she grows old she finds herself repulsive; the more she hates herself, the more she accelerates the decline of her physical and mental capacities. In her perspective, old age itself is dreadful and not the particular circumstances in which the elderly find themselves. Reason's lesson is straightforward in this respect: while it is true that certain inevitable effects of time must be reckoned with, human fulfillment depends on making the most of our allotted time in the face of death. The preparation for the afterlife is another important task of later life. Reason points out to Sorrow the universal aspect of the process of aging. Human beings are mortal, created by God from the dust and destined to return to it, as stressed in Saint Paul's epistles (Rom. 5: 12-14; 8). Yet Sorrow does not listen to Reason's advice to submit to the law of nature (II, 83, p. 196). She does not even hear Reason. She mourns her physical degradation, her illnesses, and the loss of dignity that comes with age; she laments the brevity of human life. Old age has reduced her self-esteem, and she looks at herself as a hostile stranger who has kept her ideal of youth. Reason replies that wisdom is sincere knowledge of God; the wise man goes willingly to death, whereas the wicked departs against his will. The losses that Sorrow mourns echo the words of Ecclesiastes (12:1-8), calling old age "the days of trouble... when you will say, 'I have no pleasure in them.' "

De Remediis's two books offer a treasure of meditations on a well-spent life. Throughout these debates there is a desire to mold people into idealized roles. Echoing classical, medieval, and biblical commonplaces, Reason reminds the reader that a life well lived bears riper fruit at old age, and that whatever aging may entail, no one will face it alone because God promises that "even to your old age I am here, even when you turn gray I will carry you" (Isaiah 46: 4). We often accuse the circumstances or Fortune of being responsible for our miseries, but in reality we ourselves make our lives wretched. As Reason points out, Sorrow's cause of affliction is within her, not in the biological process of aging. 
As Petrarch's dedication of De Remediis to Azzio da Correggio made clear, "those afflicted by false opinions must be healed by true maxims" (p. 10). De Remediis's commonplaces on age are not that far removed from Petrarch's self-portraits in the Letters of Old Age. These letters convey an image of old age as a state of mind and a voyage of self-discovery rather than an inevitable physiological condition. The metaphor of life as a journey is as old as thoughts on human existence; it can help us conceptualize Sorrow's and Petrarch's respective reactions to the passage of time. Sorrow looks at old age as the end of the journey of life; in contrast, in his Letters of Old Age (especially in the final letter to "Posterity") Petrarch represents his later years as a journey to life. Petrarch (and Cato the Elder in Cicero's De Senectute) praise old age as the culmination of the course of a well-led life. Sorrow, on the other hand, sees it as a diminution of life's fullness. The difference between these perspectives is not a question of fate (Fortune, good or bad, does not rule the world; only God does, Petrarch observed in his Letters of Old Age, Sen. VIII, 3) but of attitude. Man's best defense against the development of Sorrow's negative reaction to the flight of time is to acquire virtuous habits from youth onward. Following the model of Cicero's De Senectute and Seneca's Letters to Lucilius, the Letters of Old Age present the blooming of old age as the product of a life as a whole. The young man either develops "naturally" into a wise old man-such was Petrarch's own trajectory as portrayed in his Letters of Old Age-or decays into Sorrow's destructive and sterile melancholy.

\section{Castiglione}

In contrast to the moral and religious cast of Petrarch's self-portraits in the Letters of Old Age, Castiglione's presentation of the aged courtier in the Libro del Cortegiano offers an influential social and political model for later life. This model was again partly based upon classical sources that included Cicero's De Senectute. The fate of the old courtier in Castiglione's dialogue has been consistently overlooked, despite the fact that it reveals some major aspects of the author's views on court society. ${ }^{24}$

24 Teresa Ricci, “Old Age in Castiglione's Book of the Courtier," in Growing Old in Early Modern Europe. Cultural Representations, ed. Erin E. Campbell (Burlington, VT: Ashgate, 2006), pp. 57-73, gives a general description of the representation of the old courtier; Erin E. Campbell, "The Art of Aging Gracefully: The Elderly Artist as Courtier in Early Modern Art Theory and Criticism," Sixteenth Century Journal 33, 2 (2002), pp. 321-31, discusses 
The Libro del Cortegiano was a best seller in its time; first published in 1528, many French, Spanish, German, and English versions of the work circulated throughout sixteenth-century Christian Europe. ${ }^{25}$ The dialogue aimed at modeling an ideal courtier who knows how to behave with elegance and grace at court. The essential requirement was youth. The courtier must excel in sports, particularly the martial arts; in addition, a handsome appearance was de rigueur for the social entertainments of a court life in which women set the tone. A harmonious body reflected a superior mind. This combination of intellectual, moral, and aesthetic values drew heavily on the Neo-platonic ideals which underlie the book. The emphasis on physical perfection also had a practical aspect since centuries of wars on both sides of the Alps fostered a cult of virile athleticism. Throughout the book, individual identity is defined primarily through interrelationships. Age is therefore considered a predominant factor in social, political, and moral affairs: one's age permits access to certain experiences, denies access to others, and all told, embraces numerous implicit expectations. In addition, age plays a central role in the control and circulation of knowledge.

For the perfect courtier, to be old was hardly conceivable, since physical decline made it difficult to fulfill the demands of his station. In book II of the Cortegiano, Federico Fregoso, who embodies the ideal courtier's youth and beauty, cruelly mocks the old man who, despite his aging body, still dances in public and sends love letters to young women. Such a man, Federico argues, is so obviously blind to the image of himself as seen by others that he makes a fool of himself in public:

it is indeed unbecoming and most unsightly for a man of any station, who is old, gray, toothless and wrinkled, to be seen viola in hand, playing and singing in a company of ladies, even though he may do this tolerably well. And that is because the words used in singing are for the most part amorous, and in old men love is a ridiculous thing: although among other miracles, it sometimes seems that Love delights in kindling cold hearts regardless of years. (II, p. 77$)^{26}$

the relationships between the Book of the Courtier and Vasari's representation of the aging artist.

${ }^{25}$ See Peter Burke, The Fortunes of the Courtier (University Park: Pennsylvania State University, 1995).

26 Baldesar Castiglione, The Book of the Courtier, trans. C. Singleton, ed. D. Javitch (New York and London: Norton and Company, 2002). All subsequent references are to this edition and are incorporated into the text. The first number indicates the dialogue number. 
To avoid such unseemly displays, the elderly courtier is advised to desist from playing music and making love, as well as from pursuing games, arms, and dancing "before age obliges [him] to do so against [his] will" (II, p. 78). If an old man enjoys dancing and singing, let him do so, but let it be in private, Federico added. In this perspective, old age is in itself a deplorable condition. Signor Morello da Ortona, who, in contrast to Federico, is an old man, immediately objects to this characterization. Pretending to be angry, he replies: "And so it is better to rule out all old men, and to say that only young men are to be called courtiers!" (II, p. 78 ). In response, Federico observes that "every age brings with it its own cares, and has its own peculiar virtue and its own peculiar vice" (II, p. 78); he therefore criticizes old men who pretend to be young by dyeing their hair. The exchange ends with a burst of laughter among the ladies "for each of them understood that these words were aimed at signor Morello; and he seemed a little disconcerted by them" (II, p. 78).

Castiglione's protagonists define the courtier by his appearance and functional capacities rather than by chronological age. Focus on competitive physical excellence leaves little room for valorizing old age. Indeed, oppositions between youth and later life underlie the discussions of the protagonists in book II. These binary views convey an understanding of age that is divorced from individual experience as well as from the circumstances and context of this experience. By portraying the differences between "old" and "young" as extremes, such a representation assumes uniformity within these two stages of life. In Federico's discourse, the young courtier is entertaining, seductive, sociable, "spirited, generous, frank." The old one, on the other hand, is unattractive and impaired, socially dysfunctional and disengaged (II, p. 78). The latter's physical decline goes along with the deterioration of his social attitude: old men, Federico contends, are "more loquacious, miserly, difficult, and timid; are always ranting about the house, are harsh to their children, and insist that everyone should do things their way" (II, p. 78).

For centuries, these were the clichés of old age. They heavily relied on Aristotle's Rhetoric and Nicomachean Ethics - two books (along with Plato's Republic and Cicero's De Senectute, to which I shall return) that the courtier is advised to keep in mind as a reference. Older people, Aristotle added, continually praise themselves; they are shameless, and care more

I have also consulted the Italian version Il Libro del Cortegiano, ed. B. Maier (Turin: Unione Tipografico-Editrice Torinese, 1964). 
for profit than for honor. ${ }^{27}$ This bitter indictment of old age was especially popular in satirical literature and comedies; throughout the centuries, the misfortunes of the suspicious, lustful, and petty old man betrayed and fooled by youth have entertained generations of readers and spectators.

How could Castiglione possibly maintain such a negative perspective on old age? Obviously a courtier had no secret for staying young; moreover, he lived in an era when longevity among male members of his own class was on the rise, partly due to a higher infant survival rate, but also due to better hygiene and healthier eating habits. Castiglione was himself one of these aging men: he was fifty when his treatise was first published in 1528 , and many people who served as models for his characters were older. Pietro Bembo, for instance, was fifty-eight, and like many men of his generation who held key positions in the ecclesiastical hierarchy, he reached the highest offices late in life (he became a cardinal at age sixty-nine, in 1539). The Venetian republic (where the Book of the Courtier first appeared in print) provides another striking example of the political implications of age, since young and middle-aged citizens were not eligible for the most important public positions. ${ }^{28}$

It is tempting to read Castiglione's dedicatory letter of the Book of the Courtier to Don Michel de Silva, Bishop of Viseu as a nostalgic remembrance of the warm and witty court of Urbino in the early 1500 . In addition, Castiglione confesses that in reading these pages again, he was "seized by no little sadness (which greatly grew as [he] proceeded), when [he] remembered that the greater part of those persons who are introduced in the conversations were already dead" (p. 3). There follows a long list of names ending with a sad observation: the loss of "so many friends and lords... have left me in this life as in a desert full of woes" (p. 4). The author seems guilty of an error "which, as it is universally present in old people, can be thought to be proper and natural to them" - an error that his own persona condemns at the opening of book II: given the fact that the passing years have robbed him of many of the favorable conditions of life, he praises the past, and complains about the present (II, p. 65).

Despite the nostalgic tone of this dedication, however, the Book of the Courtier is not an elegiac celebration of a bygone era. ${ }^{29}$ The success of this

27 See Aristotle, Rhetoric II, 13, 1389b-1990a; Nicomachean Ethics, IV, 3, 1121, in The Complete Works of Aristotle, ed. J. Barnes (Princeton: Princeton University Press, 1984).

28 See chapter 1 , the section on Cornaro.

29 See Eduardo Saccone, introduction "The Portrait of the Courtier," in Baldesar Castiglione, The Book of the Courtier, pp. 328-41. 
work confirms that it responded to some needs specific to the context of its publication twenty years later. The author's own career illuminates some of these needs directly related to the portrait of the old courtier. When the Courtier appeared in print in 1528 , Castiglione was nuncio at the court of Emperor Charles V in Spain. In spite of the political and religious instability of the times, he still hoped to play a leading role in the emperor's and the pope's European politics. Rather than being a sign of selfish opportunism, this wish reflected his pessimism; after the sack of Rome in 1527 he had been (wrongly) accused by Alfonso de Valdès of not having prevented this tragic event. What we witness in the course of his revisions to his dialogue is a paradigm shift in the way the protagonists consider old age. Not surprisingly, this shift paralleled Castiglione's own experience as a courtier over the years.

In book II of the Courtier, Federico's negative portrait of the old courtier elaborates on representations from a bygone feudal image of the courtier as a skilled warrior in the service of his prince. Since youthful vigor was crucial to this scenario, old age signaled a time for withdrawal from the court. The Book of the Courtier was written over a twenty-year period; its various drafts gradually reduced the emphasis on arms and physical activities and placed diplomacy at the center of the relationships between the courtier and the prince. This was the perspective that was gaining momentum in internal and foreign affairs in the most powerful courts in Christian Europe, and Castiglione had a personal interest in this change. ${ }^{30}$ In the course of the dialogue, the career of the courtier moves from performance on the stage of the court to the sphere of political affairs. Alongside Federico's negative portrait of the old courtier, the second book points to commonplaces praising the old man to whom everyone turns for advice because he is "more prudent, more continent, and wiser than young men." The latter, in contrast, are "prone to quarrel, changeable, liking and disliking in the same instant, immersed in their own pleasures, and hostile to anyone who gives them good advice" (II, p. 78).

Prudence and wisdom are "acquired out of long experience," Federico notes in the second book of the Courtier (II, p. 79). The major sources of inspiration here are Plato's Republic, ${ }^{31}$ Cicero's De Senectute, and a treatise attributed to Plutarch: Whether an Old Man Should Engage in Public

\footnotetext{
30 See Amedeo Quondam, “Questo Povere Cortegiano." Castiglione, il libro, la storia (Rome: Bulzoni, 2000).

31 Plato, The Republic, trans. H. D. P. Lee (Penguin Classics: Harmondsworth Penguin, 1962), I, 1328a-b.
} 
Affairs. ${ }^{32}$ All three works are mentioned in Castiglione's treatise, and cast old men as figures of authority to be revered for their knowledge and sound judgment. Since physical and intellectual abilities peak and decline at different ages, old men should act accordingly, Federico adds. Rather than foolishly pretend to be young, they should capitalize on "the gravity of their years with a certain gentle and jocund humor."

In this way they will be good courtiers and will take much pleasure in the company of men and women, and, without singing or dancing, will be most welcome in such company at all times (II, p. 79).

This remark closes the discussion on the old courtier of the second book. The protagonists then turn their attention to other matters.

Yet the fate of the aging courtier presented a puzzling problem for Castiglione. Should old age be a time of withdrawal from public life? How could the courtier remain a key member of the court and keep the prince's confidence in spite of the physiological changes taking place in his body, and ultimately, because of them? These questions resurface in terms of continuity and adaptation by the end of the last book of the Cortegiano. Indeed, the issue was not of adding more or new qualities to this character as much as finalizing them. In the fourth book, signor Ottaviano praises the old courtier who gloriously ends his career as the prince's tutor or advisor (IV, pp. 239-41). In his work on Politics, Aristotle stated that the citizens of an ideal state should fulfill their duties according to their age, their physical strength, and their wisdom-that is, first as youthful warriors, then as experienced pedagogues and counselors to the head of the state. ${ }^{33}$ Cicero's De Senectute adopted a similar position (VI, 16-20), and so did Plutarch's treatise Whether an Old Man Should Engage in Public Affairs, which encouraged elder citizens to remain politically involved in their civic communities. ${ }^{34}$ In Castiglione's Book of the Courtier, such a view prevented potential tensions and intergenerational conflicts since it stressed obedience. The young courtier learns to act according to the ethical and political program outlined by the elder one; the old courtier, in turn, works in conjunction with the prince. From the outset, the young courtier knows that in due time he will be given the elder courtier's influential position and will have to gain the respect of every member of

\footnotetext{
32 Plutarch, Moralia, ed. and trans. H. N. Fowler (Loeb Classical Library: London, Harvard University Press, 1998), pp. $75^{-153}$.

33 Aristotle, Politics, II, 9, in The Complete Works of Aristotle.

34 Plutarch, Moralia, pp. 75-153.
} 
the court, including the prince. ${ }^{35}$ Warfare, sports, and tournaments are primarily youthful occupations; in contrast, the aged courtier has other assets than excelling in competitive games and in the battlefield, primarily his perceptive judgment.

In the second book, Federico had emphasized the wisdom of the aging courtier (II, p. 78); in the fourth book, Ottaviano elaborates on this notion by stating that the old courtier is instrumental in the transmission of power and knowledge from one generation to the next and should be responsible for the education of the prince. Speaking after Ottaviano, Bembo pushes this argument further by asserting that the courtier's political authority depends on retirement from the competitive arena of love. He thereby responds to Federico's earlier criticism of the indecorous behavior of the old man whose pursuit of love and beauty becomes the butt of satire. The importance of Bembo's speech is stressed by its length and by the fact that it is placed at the conclusion of the last book of the Courtier. Bembo's thesis can best be summed up in his own words: "the old can love without blame, and more happily than the young" (IV, p. 246). This viewpoint did not simply appeal to the tastes of an aging courtly male audience but was an effective means of maintaining a close relationship with the prince even in old age. Bembo's concluding portrait of the old courtier epitomizes the philosophical, social, aesthetic, and political ideals of Castiglione's work as a whole. It describes the courtier's transition to the most valued position in his circle: that of arbiter of the court, advisor to the prince, keeper of the court's traditions and values. This leadership partly depended on the social requirements of a milieu that favored rhetoric, and capitalized on the members of the court's intimacy and cultural homogeneity. Indeed, after a life-long practice of exchanges similar to those reported in Castiglione's work, the aged courtier knew how to influence his peers' and the prince's judgment while respecting their opinions. With dialogue comes persuasion, playfulness, and dissent; throughout the four books of the Cortegiano, the conversations between the protagonists convey different understandings of the questions under consideration; the aged courtier's familiarity with such dialectical games will help him maintain the group's harmony. As in daily conversations and courtly entertainments, he will take into account complementary and competing views. Such social and

35 The Duke of Urbino incidentally, "always retired to sleep very early after supper" (I, p. 12) the time the dialogues are supposed to have taken place. Nevertheless, the head of the court-the prince-remains one of the principal addressees of the Book of the Courtier. 
psychological skills are crucial for his political career, especially for his diplomatic missions of negotiation.

For Bembo, the aged courtier has less physical strength than in his youth but gains in influence because he is closer to the supernatural sources of power in the cosmos. The power and prestige of this character depend on his ability to reach - or, perhaps, to influence-God. Bembo defines love in Platonic terms, as "a certain desire to enjoy beauty" (IV, p. 243). Sexual desire may fool a young man, but not an old one who is no longer weighed down by his body and is guided by reason. Having climbed the ladder of love, the aged courtier's experience culminates in a contemplation in which spiritual beauty, the highest good, and the most holy love (the bond of the universe) coincide, bringing his life into a deeper union with God (IV, pp. 257-58). To indicate that his inspired utterance came from divine sources, Bembo invoked the god of love (like Socrates in the Symposium), and lost track of time during the revelation of these mysteries.

Many people are unable to reach the goal that Bembo described; moreover, only an exceptional man is capable of understanding that each step of the ladder of love leads up to the next one, and that the highest one epitomizes a transcendence of eros. Prefacing Bembo's speech, signor Morello, the elder member of the group, objected to what he considered an unrealistic perspective on love in later life. Bembo, he contended, wished old men to love in a way that he personally cannot understand: "it seems to me that to possess this beauty which he [Bembo] so much praises, without the body, is a fantasy" (IV, p. 247). This remark did not escape Montaigne's attention, as we shall see. ${ }^{36}$ As signor Morello noticed, nominal categories—be they "young" or "old" — do not map easily onto the experience of the individual.

\section{Montaigne}

Castiglione's dialogue offered an abstract perspective of old age that it did not consider either the courtier's decrepitude or his death. The view of the courtier's career as a continuous progress excluded the possibility of mental decline in later life. Bembo himself was quick to point out that the word "old" should not be taken "in the sense of decrepit or as meaning that the organs of the body have already become so weak that the soul

36 See chapter 3 , the section on Montaigne. 
cannot perform its operation through them, but as meaning when knowledge in us is in its true prime" (IV, p. 246). As such, Il Libro del Cortegiano responded to the wishes of aging gracefully of an increasing number of court members.

Over the course of the sixteenth century we witness a striking change in the ages of rulers. In 1519 the most powerful rulers in Christian Europe were in the prime of life. In France, Francis I was twenty-five; in England, Henry VIII was twenty-eight. The same year, Charles I of Spain was elected Emperor (under the name of Charles V) of the Roman Empire at age nineteen. Pope Leon $\mathrm{X}$ was in his forties, a relatively young age for such position since Renaissance pontiffs were on average aged fifty-four at the time of their election. The only exception was the eighty-two-yearold Doge of Venice, Leonardo Loredan. Venice remained a gerontocracy until 1797. A small number of young Venetians were allowed to participate in political debates to warm up the discussions, and some of them held minor public positions, yet these apparently liberal measures helped the elders to keep an eye on a few young ambitious patricians. ${ }^{37}$ The end of the sixteenth century offered a very different picture of the highest spheres of courtly life. Philip II of Spain and Elizabeth of England were well past the prime of life. In France, the Valois kings did not live long, but Catherine de Medici remained at the center of the political sphere for over a quarter of a century. In Italy as in France, old age held onto the reins of power in prescription and practice. Interestingly, Emperor Charles V's abdication at age fifty (in 1550) attracted a host of comments. Thirty years later, Montaigne still mentioned—approvingly—this event in his Essais (II, 8, p. 391/p. 343).

In the context of the French civil wars of Montaigne's time, discussions on the elders' advisory role were gaining momentum. Among French contemporary writers whose works Montaigne had read, Jean Bodin, Laurent Joubert, and Blaise de Monluc addressed the question of power and old age from different perspectives - political, medical, and military. A look at their pro-gerontocracy arguments in these fields will help to situate Montaigne's views on age and intergenerational relations within this broader intellectual context.

Jean Bodin drew his arguments in favor of gerontocracy from Plato's Laws and Republic, from history books, and works such as Cicero's De Senectute, Plutarch's Whether an Old Man Should Engage in Public Affairs

37 See chapter 1 , the section on Cornaro. 
(translated into French by Amyot in 1572), as well as from the Bible. The third book of Bodin's Six Livres de la République $(1576)^{38}$ accumulated historical and religious examples of old men's efficiency and wisdom in the political sphere. He noted that Solon forbade young men to participate in the Senate's decisions. Likewise, in Sparta, Lycurgus appointed a council of old men and this measure saved the city from anarchy as well as from the presence of dictators driven by the lust for power and self-interest. The Egyptians and the Persians also respected their elders, Bodin pointed out. The Scriptures offer similar views: God commanded the Hebrews to gather a senate of seventy old and wise God-fearing men (III, 1, p. 11/p. 255). Bodin argued that since councils of elders had been instrumental in a wide range of societies in the past, the same system in France would reinforce royal power and help reinstate peace. For Bodin, passions are dangerous, especially when it comes to making informed political decisions; they are common among inexperienced young men who lack the elders' moderation and self-control, as Plato had observed in Laws (664d, 740e). Yet age alone should not confer authority; only elders with a perceptive and sound judgment should be qualified to act as counselors. In addition, Bodin stressed loyalty, integrity, and justice as prerequisites for any role in the public sphere (III, 1, p. 12/p. 256). ${ }^{39}$

At the same time as Bodin, Laurent Joubert had different reasons to support gerontocracy. He was not in favor of a mandatory age of retirement for wise and efficient princes because he saw it as contributing to the social and political instability of the day. As a doctor, he reminded aging rulers of taking care of themselves:

A prince who takes care of his health lives longer, a most desirable thing in the eyes of his subjects. For the switching of a superior, under whom one has been nourished, to whom one has become accustomed and for whom one

38 Jean Bodin, La République, 6 vols., ed. C. Frémont, M.-D. Couzinet and H. Rochais (Paris: Fayard, 1986). The first reference is to the French edition (the numbers indicate respectively the book, the chapter, and the page; the second one refers to the page of the English translation, The Six Books of the Commonwealth. Facsimile reprint of the 1606 English translation, ed. K. D. McRae (Cambridge, Mass.: Harvard University Press, 1962). Further references are incorporated into the text.

39 Following Aristotle's Politics, Bodin also stressed the strong relationships between the republic and the family insofar as a republic is a gathering of families. The paterfamilias obviously older than his offspring - is the absolute master in his own realm; like the head of a state, his authority is incontrovertible because it is based upon nature. He rules over his wife, children, and servants until his death; more importantly, he teaches them the moral and religious values that are essential for the common welfare (I, 4, p. 20/p. 22). 
has developed affection and loyalty, is most unpleasant and most troublesome for subjects, especially since this change sometimes shakes, startles, and throws into disarray or bewilderment the condition of the nation or kingdom. We presuppose that the prince is an affable, legitimate ruler with the support of his people, subjects who would be very concerned if the good prince were not to live very long and rule over them for at least as long as a well man who took care of his health might be expected to live. ${ }^{40}$

Blaise de Monluc was also a proponent of old age's authority in yet another domain of public life, a sector usually associated with youthful vigor. Having left the battlefield at age seventy after a severe wound, he energetically advised the future Henri III to distance himself from his young "mignons" who had no military or political experience whatsoever. Stubbornly, the old Monluc kept telling the prince that young people-including Henri III himself-should listen to elders: "A young prince like you, from noble birth, the highest, and first in Christendom must always learn from old captains." A few pages later, he repeated that "youth must keep learning and must obey the elders." ${ }^{41}$ In spite of his powerful eloquence, Monluc did not obtain the military position he coveted. As his case made clear, the elder's authority was not taken for granted, hence its proponents' nagging persistence to reaffirm it. Indeed, the protestant Simon Goulart devoted a whole book to defending old age's leadership, wisdom, experience, and moral qualities. His Sage vieillard (1606) was read widely in France and in England (The Wise Old Man, 1621), ${ }^{42}$ but brought hardly any new arguments to the debate. Goulart "recycled" the same set of biblical and historical examples as Bodin, in a renewed attempt to solve a crisis that he saw mostly in moral and religious terms.

Yet how could the alleged wisdom of old age put an end to the turmoil of civil wars, Montaigne wondered. "Of Age" (Essais, I, 57) was a response and a challenge not only to Cicero's De Senectute but also to contemporary arguments in favor of gerontocracy and councils of elders. This chapter reflected the essayist's broader suspicion about abstract binary views

40 Joubert, Second Part of the Popular Errors, p. 257. On Joubert and the care of the self, see chapter 1 , the section on Montaigne.

41 Blaise de Monluc, Commentaires, ed., P. Courteault (Paris, Gallimard, 1964), pp. 801, 805, 807. "Un jeune prince comme vous et bien né, le plus grand et premier de la chrestienté, doit tousjours apprendre des vieux capitaines", "il faut que les jeunes demeurent apprentifs et obeissent aux vieux." My translation.

42 Simon Goulart, Le Sage vieillard décrit de divers autheurs (Lyon: A. de Harsy, 1606). The Wise Old Man (London: N. Bourne, 1621). 
(such as young-versus-old) and conceptual age categories. His discussion focused on historical examples and on his own experience.

Laws should take into account the nature of human existence, Montaigne observed in "Of Age." Instead of wasting their time on determining the legal onset of old age, the lawyers of the Roman Republic should have addressed the age a young Roman obtained his citizen's rights (I, 57, p. 327/p. 288). How ironic that Emperor Augustus postponed that threshold to age thirty, when he had conquered the world at about age twenty! What a waste of youthful energy and qualities! Men generally accomplish their most remarkable deeds when they are in their thirties; in addition to Augustus, the names of Alexander and Jesus immediately come to mind. For Montaigne, the old man is not qualified to take the reins of power because he belongs to a past world and has no other future than death.

Karl Mannheim's pioneering and influential socio-cultural study on "The Problem of Generations" in the 1920s provides a productive way to see the implications of Montaigne's position. Generation, as much as class, Mannheim claims, constitutes a formative factor for social groups; it links its members together not simply by their biological age, but also through shared experiences at a specific historical moment and exposures to particular aspects of cultural memory at a certain stage of their intellectual development and social integration. ${ }^{43}$ This is why, Mannheim observes,

While the older people may still be combating something in themselves or in the external world in such fashion that all their feelings and efforts and even their concepts and categories of thought are determined by that adversary, for the younger people this adversary may be simply non-existent: their primarily orientation is an entirely different one. (p. 299)

The conceptual and epistemological gap between older and younger people opens up moments of "fresh contact." On the one hand, youth's interaction with an inherited socio-cultural order "results in some loss of accumulated cultural possessions;" on the other hand,

it alone makes a fresh selection possible when it becomes necessary; it facilitates re-evaluation of our inventory and teaches us both to forget that which is no longer useful and to covet that which has yet to be won. (p. 294)

43 Karl Mannheim, "The Problem of Generations," in Essays on the Sociology of Knowledge, ed. P. Kecskemeti (London: Routledge and Kegan Paul Ltd, 1959), pp. 276-320; see especially p. 290. Further references are to this study and are incorporated into the text. 
Mannheim's conceptualization of the generational process retains room for difference as well. First, it acknowledges each generation to be a composite rather than a monolith, consisting of multiple differentiated units, split along nuanced socio-cultural and economic lines. Second, it posits the notion of a "generational site" or a "common location in the historical dimension of the social process."

... so that "the youth" experiencing the same concrete historical problem may be said to be part of the same actual generation, while those groups within the same actual generation ... work up the material of their common experience in different specific ways, [and] constitute separate generational units (p. 304).

Mannheim's basic assumptions remain unchallenged, at least in the case under consideration: the chapter "Of Age" in the Essais capitalizes on moments of "fresh contact." For Montaigne, the old man who confronts a new situation has a framework of useable past experiences so that, as Mannheim writes, "every new experience has its form and its place largely marked out for it in advance" (p. 296). Consequently the elder tends to keep repeating his previous experiences and is unable to evolve with the rest of the world; he is so used to the way things were that it might be difficult for him to go beyond his habitual thought patterns. The young man who does not have such a long past is more likely to adapt to a changing world and to consider new perspectives. In the twentieth century, Albert Einstein declared that we cannot solve problems through the same kind of thinking as when we created them. Montaigne similarly noted that as we age, yesterday's ways of reasoning form an invisible box out of which old persons resist venturing. Young people do not tackle questions the way their parents and grandparents did because they do not know these previous methods, and thus they are more likely to find new approaches. There is a certain fearlessness in ignorance that Montaigne admires, although paradoxically it is obvious to the reader that Montaigne's own case is an exception to the rule: the essayist's aging brain and vast erudition give him great insights into creativity and innovation.

Nevertheless, "All things have their season," he contended in another chapter ("Toutes choses ont leur saison," II, 28, p. 702/p. 644). As Montaigne grew old, he claimed to be "fall[ing] far from [his] early vigor and cheerfulness, and beginning to grow withered and rancid." He added: "I am at the bottom of the barrel, which begins to taste of the lees." "descheu de ma premiere vigueur et allegresse, tirant sur le flestry et le rance. Je suis sur le fond du vaisseau, qui sent tantost le bas et la lye" (II, 37 p. 784/p. 
724). Still, he was fully aware that there are no definitive judgments on anything (especially the self), because there are no objective criteria for evaluating things but only discrepancies between the many ways things appear to us. In contrast to Cicero's unconditional praise of Cato the Elder's sound judgment in De Senectute, Montaigne was convinced that an individual does not necessarily become wiser as years go by. He thought that in certain ways he had the same amount of wisdom in the prime of his life as in his fifties, although the "quality" of his wisdom was different according to his age (III, 2, p. 816/p. 752). ${ }^{44}$ In addition, what exactly is the nature of the alleged wisdom of old age? He noted that the acquisition of such quality is often the result of external circumstances and coincidences rather than a matter of accrued experience. In Job's words, "It is not only the old who are wise, not only the aged who understand what is right" (Job 32: 19). Montaigne even believed that to some extent, Socrates had lent himself to his condemnation to death, "being seventy, and having so soon to suffer an increasing torpor of the rich activity of his mind, and the dimming of its accustomed brightness" "ayant de si pres, aagé de soixante et dix ans, à souffrir l'engourdissement des riches allures de son esprit et l'esblouissement de sa clairté accoustumée," III, 2, p. 817/pp. 752-53).

He was not the first Renaissance writer to criticize gerontocracy. In his Discourses (a work Montaigne certainly knew), Machiavelli praised the Romans of the early Republic who judged the candidates for political positions on their skills rather than on their age. ${ }^{45}$ His remark targeted his fellow Florentine citizens who did not consider a man under the age of twenty-nine for any key public function. In Art of War, Machiavelli went one step further, and accused the old Florentines of being responsible of the city's humiliation because of their conservatism and passive resignation. ${ }^{46}$ Guicciardini, Varchi, and Vettori, who were also in favor of the giovani, similarly saw old rulers as an obstacle to political liberty and democracy. ${ }^{47}$

\footnotetext{
44 "ma sagesse peut bien estre de mesme taille en l'un et l'autre temps [en ma jeunesse et en ma vieillesse]; mais elle estoit bien de plus d'exploit et de meilleure grace, verte, gaye, naïve, qu'elle n'est à present: croupie, grondeuse, laborieuse" (III, 2, p. 816).

45 Niccolò Machiavelli, Discorsi sopra la prima Deca di Tito Livio (libri III). Dell'Arte della guerra. Dalle Legazioni, ed. R. Rinaldi (Turin: UTET, 2006), p. 10.

46 Machiavelli, The Art of War, trans. C. Lynch (Chicago: Chicago University Press, 2003), pp. 37-42.

47 Richard Trexler, Public Life in Renaissance Florence (New York: Academic Press, 1980), pp. 396, 510. John M. Najemy, A History of Florence, 1200-1575 (Malden, Mass.: Blackwell, 2006), pp. 375-413.
} 
Young men represent the future and should take the leadership because they bring social rejuvenation; old men should withdraw from public affairs, such was the essayist's contention in "Of Age." Yet did his personal career really correspond to such views? Montaigne retired in 1571, at age thirty-eight; he thought that he had lived the major part of his life and that death was approaching. His decision did not prevent him from serving as the mayor of Bordeaux for two terms in a row some years later. Indeed, his retreat was a way to maintain a balance between his professional obligations and his attempt to know himself. As he wrote in the chapter "De Mesnager sa volonté" (III, 10, pp. 1004-5/ "Of Husbanding your will," pp. 932-33), he fulfilled his professional duties as best he could, but always saw them as a temporary performance on the stage of the world.

Political action can take many forms. As Plutarch (one of Montaigne's favorite authors) contended at the end of his treatise Whether an Old Man Should Engage in Public Affairs, ${ }^{48}$ an old man can give his fellow citizens sound and frank advice without being appointed as the prince's counselor or advisor. To what extent did Montaigne's restless efforts to promote his Essais at the court (he went to Paris to offer his work's first edition to Henri III in 1580) correspond to Plutarch's remark? In contrast to Cato the Elder in De Senectute, he never claimed to be a role model for his readers; yet in a time of civil wars and fanaticism, his work opened up insightful ways to question prejudices and to fight intolerance by exercising one's judgment on a variety of topics. ${ }^{49}$

No age of life stands alone; "generations are in a state of constant interaction," Mannheim noted (p. 301). Montaigne saw this relationship in terms of cooperation rather than of power and authority; the elder teaches the young person, and vice-versa. ${ }^{50}$ As he grew old, he claimed to be more receptive to younger people's ideas. Was his elasticity of mind and his openness to new ideas the result of a lifelong experience? In certain spheres, a man may achieve a greater adaptability in his later years than in his youth because he is in a better position to distance himself from his "original approach," Mannheim observed (p. 302).

Nowhere is the link between generational tensions and social practices stronger than in matters of inheritance of wealth and estates. Countless

\footnotetext{
48 Plutarch, Moralia. pp. $75^{-153 .}$

49 See Géralde Nakam, Les 'Essais' de Montaigne, miroir et procès de leur temps. Témoignage historique et création littéraire (Paris: Champion, 2001).

50 His considerations on education strike a similar note, and emphasize the bond between the child and his tutor (I, 26).
} 
authors (from Plautus, Terence to Molière on) have elaborated on the conflicts between almighty fathers and powerless children in humorous, tragic, pathetic ways. Likewise, Montaigne's chapter "De l'affection des pères aux enfans" (II, 8, "Of the affection of fathers for their children") includes contemporary stories of despotic fathers who refused to hand properties over to their sons and daughters, resulting in desperate acts. For Montaigne, the lesson is clear: the abusive paterfamilias brings destruction on his relatives and destroys himself as well; only mutual affection, dialogue, and respect among members of different generations are fruitful. Consequently, old men should delegate the ordering of their estates to their children, who can cope much better with such weighty matters. Obviously, such a view applied only to upper-class, wealthy families. In Montaigne's case, the problem of inheritance was complicated by the fact that without a son he was the last male of his lineage. He had a young daughter, and told his readers that he would gladly have left the management of his estate to his future son-in-law, passing on to him such daily worries (III, 9, p. 953/p. 882). Despite his liberality and lack of interest in practical matters, he did not squander his inheritance, and even increased it with a non-transferable honorific title of "Citizen of Ancient Rome," he ironically noted in "Of Vanity" (III, 9, pp. 999-1000/pp. 930-31).

Here and elsewhere, his comments stemmed from his personal experience and from his dialogue with books. The last additions to the Essais indicate that he was rereading De Senectute in his later years; indeed, some of his self-portraits capitalized ironically on the stereotypical weaknesses of old age catalogued by Cato the Elder. Cicero's protagonist was a dynamic old man who never wasted an instant, whereas Montaigne claimed to devote himself to the delights of idleness. In reality, his alleged leisure produced the Essais, which obviously required a great deal of work, but he was one of those people for whom old age and retirement meant the possibility of fulfilling a hitherto suppressed literary vocation. An exemplary character in every respect, the octogenarian Cato the Elder denied his physical and intellectual decline; in contrast, Montaigne exaggerated the negative impact of age on his body and his mind: from his thirties on, he was certain that "since that age [his] mind and [his] body ha[d] rather shrunk than grown, and gone backward rather than forward." (I, 57, p. 327/p. 289). Each of Cato's activities had a rational explanation and a clear purpose in De Senectute: he increased the value of his property by cultivating his land, read books to learn from them, discussed with young men to pass on his lifelong experience to the next generations. Montaigne shared some of these interests, but claimed that he did not 
pursue any specific goal and that he was unable to focus his attention for a long time on anything. He glanced over books without reading them systematically, and considered them as an entertaining pastime rather than as a source of knowledge. Spending later life's leisure in bookish studies, as Cato the Elder did, seemed to him nonsensical. Such claims served to justify the informal essay genre. ${ }^{51}$

\section{Conclusion}

Each of the writers discussed in this chapter adapted classical sourcesincluding Cicero's Cato Maior De Senectute - to different historical circumstances. Methods of appropriation range from direct references to previous texts, to combinations of different models, and subversion of their meaning. My discussion has focused on these aged writers' responses to the turmoil of the day: whether they favored gerontocracy, councils of elders, or social rejuvenation, Petrarch, Castiglione, and Montaigne and his contemporaries strove for peace and political harmony. Their works built communities of readers by offering ways to think about the political and social tensions of the day in terms of intergenerational dialogue.

Competition, authority, withdrawal, and subordination are only a few of power's modes of expression when dealing with intergenerational relations. On the one hand, the respect due to the elder became a justification of social continuity in works as different as Petrarch's Letters of Old Age, Castiglione's Book of the Courtier, Bodin's political treatise Les Six livres de la République, Joubert's medical observations in Les Erreurs populaires, and Monluc's memoirs of a soldier. On the other hand, the defense of gerontocracy, councils of elders, and more broadly speaking, of stereotypes of age came under scrutiny. Writers such as Montaigne unmasked their inconsistencies and questioned their binary views of old-versus-young.

Interestingly, the old-versus-young confrontation has recently become a renewed focus of attention insofar as from the late 1980s on, increases in retirement age in the Western world have reversed a century-long trend towards earlier retirement. A Gallup poll released on April 2010 notes that "Americans' projected retirement age continues to creep up."52 People are

51 See also chapter 4 , section 3 on this point.

52 http://www.gallup.com/poll/127514/Americans-Projected-Retirement-AgeContinues-Creep-Up.aspx?utm_source $=$ tagrss\&utm_medium $=$ rss\&utm_campaign $=$ syndication\&utm_term=All\%2oGallup\%2oHeadlines. 
holding onto their jobs, and "older workers are replacing younger workers in the labor force." ${ }^{53}$ The current change in the age composition of the working population depends mostly on the uncertainty about our own future economic environment, ${ }^{54}$ yet the growth in the employment of individuals over age sixty-five may also be responding to broadermore philosophical and sociological-reasons, including the prospect of longer life spans or matters related to an individual's well-being and lifestyle. Some could argue, for instance, that in ideal conditions, working longer might help elders from the middle class stay intellectually alert and actively involved in their community. Others, on the other hand, may stress the psychological benefits of an early retirement such as peace of mind or more time allotted for leisure and family activities.

Petrarch and Montaigne, for their part, explored the relations between aging and self-knowledge. The aged Petrarch saw himself as different from his previous, youthful persona, and claimed to have a better understanding of his condition. His later life was a time of literary and personal cohesion; he completed unfinished texts and recollected the fragments of his own past. In a letter written to Boccaccio in 1373, a year before his death, Petrarch noted, "I am aroused, however late, to correct with God's favor what was missing not only from my life, but also from my writings" (Sen. XVII, 2, p. 647). ${ }^{55}$ In yet another epistle of his Letters of Old Age, he stressed his ability to cope with the blows of fortune, and gratefully acknowledged the weakening of his youthful lust. He then thanked old age, God, and books for granting him peace of mind (Sen. VIII, 2, p. 275/Lettres, vol. 3, p. 57). For Petrarch, youth was a gift of nature, but old age was a work of art. Montaigne, for his part, represented his experience of growing old in a less straightforward and more complex manner. He watched himself grow old "by pieces" rather than follow an ascending path from youth to old age. Decline and growth go hand in hand throughout the life course, he observes in the chapter "Of Experience": "le declin praeoccupe son heure et s'ingere au cours de nostre avancement mesme"

53 Read On ABC News Radio: http://abcnewsradioonline.com/business-news/young-peoplestruggle-to-find-jobs-while-elders-hold-on-long.html\#ixzz26CewVYC 3 , Accessed March 14, 2013 .

54 In the United States, the long-term viability of Social Security, potential benefit reductions, the health care and long-term costs play a major role in decisions to delay retirement.

55 "expergiscor, ut favente deo emendem-vero licet-in me, non solum quod vite defuerit, sed etiam scripture." On the same topic, see also Sen. XII, 1, p. 439/ Lettres, vol. 4 , pp. $15^{-17}$. 
(III, 13, p. 1102/ "Decline mingles and fuses with our life throughout," p. 1031). Since improvements and weaknesses are inseparable, he capitalized on the stereotyped negative effects of aging that fitted the informal genre of the essay. This process reinforced his feeling of the polyphony of the self. ${ }^{56}$

For Montaigne as for Petrarch, growing old brought an awareness of otherness. Their respective comments on love in old age were an important part of this perception, as we shall see in the next chapter.

56 See chapter 4, section 3 . 